\title{
Bank risk - return efficiency and bond spread: Is there evidence of market discipline in Europe
}

\author{
Cécile Casteuble ${ }^{1}$, Emmanuelle Nys, Philippe Rous \\ Université de Limoges, LAPE ${ }^{2}$
}

\author{
Very preliminary version - March 7, 2013 \\ Please do not quote without the permission of the authors
}

\begin{abstract}
The aim of this paper is to empirically investigate the relationship between bank risk-return efficiency and bond spread priced in the primary market. Our study is based on a sample of European listed banks for the period 1996-2011. Applying a parametric frontier based on the Battese and Coelli (1993) model, we can compute risk-return efficiency score for each bank at each date. Compared to previous studies, we investigate the effectiveness of market discipline taking into account not only risk and return independently, but also the level of profitability for a given level of risk on the pricing of bond spread. We find that, over the complete sample period, bondholders require a higher spread from more inefficient banks. A closer analysis actually shows that market discipline is not effective during sound economic period, but market investors comes to discipline banks during distressed economic period by pricing lower spread to more efficient banks.
\end{abstract}

JEL Classification: G21, G24, G28, G32

Keywords: bank efficiency, risk-return efficiency, bond spread, market discipline, stochastic frontier analysis

\footnotetext{
${ }^{1}$ Corresponding author: cecile.casteuble@unilim.fr (C. Casteuble Tel: +33 5551492 05)

${ }^{2} 5$ rue Félix Eboué, 87031 Limoges Cedex, France
} 


\section{Introduction}

The increasing size and complexity of the financial system has made the regulation growing sharply through years, accounting for an increased desire to control banking activities and to avoid systemic crises in protecting bank safety. In particular pillar 3 of Basel II Accords suggests to reinforce the action of market discipline channels by strengthening information disclosure ${ }^{3}$. The reform aims to provide more information to markets actors, such as bondholders or shareholders, which can then exert a direct monitoring and influence on banks. Indeed market investors incorporate their evaluation of a bank condition in its assessment (through for example its security price or its bond spread). This monitoring may prompt firm managers to take corrective measures to counteract adverse changes (Bliss and Flannery (2002)). While market discipline has become an important tool to complement banking supervision, its effectiveness as a prudential mechanism is still under assessment. The present financial crisis, started in 2007, shows that market discipline was insufficient to limit excessive risktaking by banks.

The purpose of this paper is to empirically test whether bondholders exert a discipline on how banks manage their level of risk with regard to their profitability. More precisely do bondholders discipline banks that mismanaged their risk? Does the bond spread account for the bank risk - return efficiency? Empirical studies on bond spread evaluate whether the market reacts to bank risk taking, but they do not take into account its risk management. These studies consider the effect of the level of risk on bond spread, and expect that a higher level of risk should induce a higher spread. In this study we do not only consider that the level of risk should impact bond spread, but rather the efficiency of risk taken by banks, that is we take into account the couple risk-return. In other words, we assume that the market is considering the bank efficiency to price its debt. The market will not only penalize high risks; it will sanction bad efficiency that is banks which do not optimally manage their risks, even if the level of risk is low ${ }^{4}$. We aim to assess whether the market takes into account the efficiency of the couple risk/return and not only risk taking. Let's consider two different banks which take the same level of risk: we consider that the first one is efficient and it therefore belongs to the efficient frontier. The second bank on the other hand has a level of profitability that is lower than the first one. This bank, independently of the level of risk taken, should have a higher bond spread than the first one. In other words, market investors will react and send a signal to the bank by requiring an increased bond spread. The bank has to improve the efficiency of the couple risk/return either by improving its risk management process, that is increasing its profitability, or by decreasing its degree of risk given its level of return. Therefore the efficiency of the management of the bank, through its choice of risk and return, should be considered while assessing market discipline. Our research question is then to

\footnotetext{
${ }^{3}$ See Board of Governors of the Federal Reserve System (1999)

${ }^{4}$ It means that market discipline forces banks to shift their portfolio in order to reach an optimal risk-return frontier.
} 
examine how banks' risk-return efficiency affects their financial cost measured by the spread at the issuance of unsecured bonds.

In the literature, a large number of studies show that subordinated debt or unsecured bonds are a good instrument of market discipline (BGFRS (1999), Evanoff and Wall (2001) and Evanoff et al. (2011)). Among them, banks' bond spread is widely used to evaluate market discipline as its level reflects the additional compensation required by bondholders to hold the bond instead of a default-free government bond (Elton et al. (2001)). In this paper we add to the literature by further studying the effectiveness of market discipline while including the risk-return efficiency as a determinant of bond spread. Previous papers have empirically examined to which extend bank risk and profitability impact bond spread of banks. They evaluate the relationship between bond spread and bank risk characteristics and try to show that bondholders ask for higher premium from riskier banks and less profitable banks ${ }^{5}$. Flannery and Sorescu (1996) study if there is evidence of market discipline over the period 1983-1991 on US banks. They used an option-adjusted subordinated debt spread extracted from the secondary market and examine the impact of bank risk on the spread. They find that market discipline becomes effective when regulators stopped protecting large bank holding companies' creditors. The effect of the profitability measure on bond spread is ambiguous as its coefficient can have a positive or a negative sign. Morgan and Stiroh (2001) analyze the existence of market discipline for US banks and BHCs on a large panel of bonds issued between 1993 and 1998. They found that market discipline is effective, more precisely they found that riskier banks and less profitable banks have a higher bond spread. They also show that bond spreads are sensitive to assets bank portfolio. Jagtiani et al. (2002) test the relationship between secondary market bond spread and US banking risk. They find that risk factors affect the bond spread either for BHCs and banks. They also found that profitable and risk variables are significant with respectively a positive and negative sign. Sironi (2003) studies the relation between the primary bond spread and risk over 1991-2000 and for a sample of 290 banks issues. He finds a negative sign for the profitability variable but no relationship between the spread and accounting risk measures. However through ownership Sironi shows that risk matters as state-own banks have a lower spread than the other banks. Pennacchi and Iannotta (2012) are interested in the systemic risk as a component of bond spread. On a sample of 3,924 bonds issued by US, Japan or European banks over 1999-2010, they show that bondholders sanction banks which take excessive systematic risk. They do not control for profitability. Pop and Pop (2012) use a quantile regression on a panel of 521 bonds issued between 1995 and 2002 to test whether market investors are tougher with high-risk bank and show that bond investors ask for a higher bond spread from banks that are taking higher level of risk.

\footnotetext{
${ }^{5}$ However the link between market discipline and profitability is ambiguous. A greater profitability could also increase the spread as it may result from greater risk-taking.
} 
In this paper, we extend the previous literature by considering the risk-return efficiency of banks while assessing the effectiveness of market discipline. In the aforementioned papers, authors show that the pricing of bond spread reflect the bank level of risk, but no one is addressing the question of banks risk-return management impact on bond spread. We add a new variable, the risk-return efficiency score, as a determinant of the bond spread equation instead of introducing profitability and risk components independently. We work on a set of 47 listed European banks that issued 1585 unsecured bonds between 2001 and 2011. Our empirical analysis aim to test our research hypothesis, that is whether the management of risk, measured by a risk-return efficiency score, is taken into account in the pricing of bond spread. We undertake this study in two steps. First, we use a stochastic parametric frontier methodology to determine the bank efficiency in the management of their risk-taking. In the second step, we model the bond spread equation with the common variables used in the literature to which we add the risk-return efficiency score as a determinant of the bond spread equation instead of introducing profitability and risk components independently.

Overall our results suggest that a lower risk-return efficiency score, i.e. an increased inefficiency, is associated with a higher bond spread. However if we consider more closely this finding, we show a change over the period in the behavior of market investors. Before the financial crisis bondholders are seems to prefer risk-taking behavior. On the contrary since the beginning of the crisis, market investors required from banks higher bond spread not only when risk increases but also when inefficiency increases. More generally, we show that during time of distressed economic period (low GDP growth), market discipline is effective. Market investors require higher bond spread to more risky and more inefficient banks. Such a requirement disappears during sound economic period.

The remainder of this paper is organized as follows. Section 2 describes our data and sample, and provides some descriptive statistics. Section 3 describes the methodology to calculate the risk-return efficiency score and to estimate the determinant of bond spread, while our results and robustness checks are presented and discussed in section 4 . Section 5 concludes.

\section{Data, sample, and variable characteristics}

\subsection{Data and sample}

Our sample contains investment, commercial and saving banks from 14 European countries: Austria, Belgium, Denmark, France, Germany, Greece, Ireland, Italy, Luxembourg, Netherlands, Portugal, Spain, Sweden and United Kingdom. Initially 218 banks were identified in the FitchIBCA Bankscope database. The whole set of accounting data come from Bankscope. After collecting daily stock market data from Datastream, we applied a criterion of trading regularity to these European publicly and traded bank set, which leads us to remove banks for which trading prices remain constant over more than $30 \%$ of the whole trading days over the period 1996 - 2011. Our final sample consists of 166 banks. This dataset is used to estimate the risk-return efficiency scores over the period $2001-2011$. 
For this bank set, we identify within Bloomberg database bonds satisfying the following criteria: we only include standard bonds ${ }^{6}$ issued between 2001 and 2011 with fixed coupon rate, no-early redemption (bullet) and no option features (non-callable, non-perpetual, non-putable, non-sinkable and non-convertible $)^{7}$. All these bonds are unsecured or subordinated. We indifferently include matured and non-matured bonds. Bonds should be rated, at the immediate neighborhood of issuance, by at least two credit rating agencies (Moody's, Standards \& Poors and Fitch). We exclude issues with a very short maturity and perpetual bonds that do not have a maturity date in order to calculate a spread ${ }^{8}$. Merging the two dataset leads to a final sample including 1,585 bonds issues originated by 47 banks. The number of banks and bond issues from each country are shown in Table 1.

\section{[Insert Table 1 about here]}

\subsection{Bond spread, rating and descriptive statistics}

Our study is based on primary market spreads as Morgan and Stiroh (2001), Sironi (2003), Iannotta et al. (2011), and Pennacchi and Iannotta (2012). Bond yields come from Bloomberg Database. We compute bond spread, SPREAD, as the difference between the bond yield at issuance and the implicit yield of a same currency and maturity Treasury bond ${ }^{9}$. The yield of the risk free benchmark is interpolated, for a given maturity, as in Morgan and Stiroh (1999), Jagtiani et al. (2002) and Sironi (2003). For bonds issued in a currency prior the Euro, the spread is calculated using a Treasure security issued in the same currency and with the same maturity as the bond.

Beside bond spreads, we have collected detailed information about issues (issue date, maturity, amount issued, currency coupon rate, ratings by the three main rating agencies etc.) and about issuers (Moody's and Fitch rating at issuance, ownership structure etc.). For each bank, we gather two kinds of rating: traditional rating (Moody's Issuer Rating and Fitch Long term Issuer Default Rating) and solidity/individual rating (Moody's Bank Financial Strength Rating (MBFS) and Fitch's Bank Individual Rating (FBIR)). Financial strength ratings are different from traditional ratings as they exclude a potential influence of a safety net effect. They show the true financial condition of banks without any regard to safety net effects. We convert ratings into numeric value according to rating scales available in appendix A1. Higher numerical value means lower rating and thus higher risk as perceived by rating agencies. We create three variables: RATINGBOND is the average of bond ratings for each bond at each date; likewise RATINGTRAD is the average of the issuer traditional ratings from

\footnotetext{
${ }^{6}$ We choose traditional plain-vanilla bonds in order to slip option, fiscal and liquidity premium component of bond spread and keep mainly the risk premium part (see Elton et al. (2001)).

${ }^{7}$ As in Sironi (2003), Iannotta (2008) and Jagtiani et al. (2002)

${ }^{8}$ When maturity is close to a week or more than fifty years, we do not have a value for the risk free rate and thus we cannot compute bond spreads.

${ }^{9}$ As extreme value of bond spread exist, we winsorized it.
} 
Moody's and Fitch, and, RATINGSOLID is the average of bank individual/financial ratings. Table 2 reports information on spread, maturity and rating classes through years.

\section{[Insert Table 2 about here]}

\section{Methodology}

\subsection{Risk-return efficiency score: a stochastic frontier approach}

\subsubsection{Risk-return frontier}

We postulate that some banks do not manage their risk - return choices as efficiently as it would be possible on the basis of what can be observed. These banks are risk-return inefficient because their trade-off between risk and return is not optimal as regard with the so called, period contingent, best practice frontier $(B P F)$ and can be improved. For a given period, this $B P F$ can be computed using two main methods: the Data Envelopment Analysis $(D E A)$ or the Stochastic Frontier Analysis $(S F A)$. We prefer $S F A$ as, unlike Data Envelopment, it decomposes the distance to the $B P F$ into two components: an inefficiency part and a stochastic one, avoiding to interpret what would be a simple stochastic shock as a full inefficiency gap. The estimation of the risk-return $B P F$ allows us to provide, at each date and for each bank, a risk-return efficiency score which summarizes the relative position of the bank compared to the $B P F$ measure of bank risk-return efficiency. The efficiency score takes its values between zero and 1 ; as the score gets closer to 1 , the more efficient the bank will be.

We measure the bank's profitability as the return on average assets $(R O A)^{10}$. We choose $R O A$ rather than $R O E$ (returns on average equity) as, for a given level of risk, a fall of $R O E$ from the $B P F$ may equally result from a true profitability downturn (which should be disciplined) or from a rise of the capital ratio (which should not). It should be noticed that the profitability measure is available at an annual frequency. To measure bank risk, we consider a market-based indicator. This market based measure is calculated using daily stock market data. $R T O T_{i, t}$ is the standard deviation of daily bank stock returns $\mathrm{R}_{\mathrm{i}, \mathrm{t}}$ computed on a moving window of 261 quoted days [t-261, t], see Baele et al. (2011) or De Jonghe et al. (2012). This risk indicator is available at a daily frequency. As the profitability variable is available at an annual frequency, the high frequency data for bank risk have been averaged for each year from 1996 to 2011. As DeYoung et al. (2001-b), we rescaled our return and risk measures by their respective standard deviations.

As our aim is not to explain the inefficiency level for bank $i$ at time $t$ but to analyze the effect of this inefficiency on the pricing of bond spreads, we compute the risk-return stochastic frontier and the

\footnotetext{
${ }^{10}$ ROA is regularly used as measure of profitability in the spread equation see Flannery and Sorescu (1996), Morgan and Stiroh (1999), Deyoung et al. (2001-a), Jagtiani et al. (2002), Sironi (2003), Evanoff et al. (2011), Pop and Pop (2012)
} 
induced efficiency scores on the basis of Battese and Coelli (1993), where the BPF is based on the equation:

$$
R O A_{i, t}=\alpha+\beta R T O T_{i, t}+\varepsilon_{i, t}
$$

with: $\varepsilon_{i, t}=v_{i, t}-u_{i, t}$

$R O A_{i, t}$ is the profitability measure of bank $\mathrm{i}$ at time $\mathrm{t}$ and $R T O T_{i, \mathrm{t}}$ is the risk measure of bank $\mathrm{i}$ at time $\mathrm{t}$. Equation (1) looks like a production function were risk would be the input variable and profitability the output. The error term $\varepsilon_{i t}$ is time and bank-specific and is equal to $v_{i, t}-u_{i, t} \cdot v_{i, t}$ is a two-sided random component reflecting exogenous shocks for which banks cannot be accountable from an inefficiency point of view. $v_{i, t}$ is assumed to be normally distributed $v_{i, t} \sim N\left(0, \sigma_{v}\right)$. The inefficiency component $\mathrm{u}_{\mathrm{i}, \mathrm{t}}$ is assumed to be drawn from a half normal distribution with zero mean and variance $\sigma$ :

$$
\mathrm{u}_{\mathrm{it}} \sim \mathrm{N}+(0, \sigma)
$$

The sample log-likelihood (see Battese and Coelli (1993)) is maximized with regard to $\alpha, \beta,\left(\sigma_{v^{2}}+\sigma^{2}\right)$ and a parameter $\gamma$, equal to $\sigma^{2} /\left(\sigma_{v}^{2}+\sigma^{2}\right)$, which measures the relative contribution of the inefficiency component to the determination of the volatility of $\varepsilon_{\mathrm{i}, \mathrm{t}}$. We used the SFA function of the FRONTIER package to implement this estimation with R software.

\subsubsection{Risk-return efficiency score}

Once the parameters of the model have been estimated, we can calculate the estimated efficiency scores, for each bank at each date. These efficiency scores will next be used as a determinant of bond spreads. Therefore, we chose to not estimate them directly on the whole sample period $1996-2011$, even if Battese and Coelli (1993) allow such a possibility: indeed, this procedure would inconveniently suggest that market investors hold the whole future information when they have to evaluate bank efficiency at time $t$.

To estimate our efficiency scores, we prefer to estimate the $B P F$ given all past information we hold. We estimate our first score in 2001, using a $B P F$ based on all the information available between 1996 and 2001. Then to estimate the efficiency score in 2002 we use a $B P F$ based on information available between 1996 and 2002 and so on. Nonetheless, while we calculate our frontiers, we observe that the theoretical positive relationship between return and risk is altered through time. More precisely, since the beginning of the financial crisis, we either have no relationship or a negative one. Such a result can be explained by the realization of risk during this strong distressed period, high-risk profile bank end up with a low profitability. Figure 1 in appendix A2 shows the evolution of our $B P F$ through years.

To compute our efficiency score, we cannot keep a $B P F$ with a negative slop. Indeed, let's suppose we do so (like the $1996-2011 B P F$ ). Bank A on figure 1 would get a better score, that is closer to 1, than 
bank B, when obviously an investor would prefer bank B, which offers the same profitability as bank A but for a lower risk. Therefore, we assume that investors, bondholders, do not consider the frontier obtained during the financial crisis as $B P F$. To calculate these risk-return efficiency scores during the year of the financial crisis, we suppose that investors refer to the last $B P F$ with a positive relationship between risk and return $(1996-2008)$.

Table 3 hereafter resumes some descriptive statistics for the estimates of the stochastic frontier parameters and Table 4 presents the mean efficiency scores through years. Summary statistics for the profitability and the risk measures as for the risk-return efficiency score are presented in Table 5.

\section{[Insert Tables 3, 4 and 5 about here]}

\subsection{The spread equation}

To determine whether bond market investors discipline banks for risk-return inefficiency, we estimate different equations of bond spread' determinants on the basis of the following general specification:

$$
\operatorname{SPREAD} D_{j}=\alpha+\beta S C O R E_{i(j), t(j)}+\gamma Y_{i(j), t(j)}+\theta X_{j}+\tau Z_{t(j)}+\varepsilon_{j}
$$

The dependent variable $S P R E A D_{j}$ is the spread at issuance for bond $\mathrm{j}$, issued at time $\mathrm{t}$ by the issuer $\mathrm{i}$ of bond $\mathrm{j}$. The spread is the difference, in basis point, between the bond yield at issuance and the yield of a same currency and maturity Treasury Bond (Jagtiani et al.(2002)) ${ }^{11}$. $Y_{i(j), t(j)}$ is a vector of interpolated bank-specific accounting variables for bank $\mathrm{i}$ at time $\mathrm{t}^{12}, X_{j}$ is a vector of bond $\mathrm{j}$ characteristics and $Z_{t(\mathrm{j})}$ is a vector of control variables that may affect bond spread. Table 6 provides a short description and some general descriptive statistics of these explanatory variables.

\section{[Insert Table 6 about here]}

$S C O R E_{i(j), t(j)}$ is the interpolated value of the risk-return efficiency score at issuance (day t). We assume that the market is able to evaluate the bank risk-return inefficiency and that it prices bonds accordingly. $L I Q D E P_{i(j), t(j)}$ is the ratio of liquid assets to customers deposits and short term funding (Sironi (2003) and Pop and Pop (2012)). We expect a negative sign, more liquid bank should be safer and thus the spread should be lower. $L E V_{i(j) t(j)}$ is the ratio of total liabilities to total equity (Flannery and Sorescu (1996), Jagtiani et al. (2002), and Sironi (2003)). Traditionally, a higher leverage ratio

\footnotetext{
${ }^{11}$ For bonds issued in a currency prior Euro, the spread is calculated using a Treasure Bond issued in this currency with the same maturity as the issue.

${ }^{12}$ The bank-specific accounting variables $Y_{i(j), t(j)}$ as well as the risk-return efficiency scores have to be time-interpolated. These variables are observed (or computed) at December $31^{\text {th }}$ of each year and for each bank issuer whereas bonds can be issued at any time during this year. For an issue $\mathrm{j}$ at time $\mathrm{t}=$ March $31^{\text {th }}, 2007$, the matching value for $\mathrm{Y}_{\mathrm{i}(\mathrm{j}) \mathrm{t}(\mathrm{j})}$ will be $0.75 \times$ $\mathrm{Y}_{\mathrm{i}, 2006}+0.25 \times \mathrm{Y}_{\mathrm{i}, 2007}$.
} 
means a higher default risk leading to a higher spread. TAMAX $X_{i(j), t(j)}$ is the ratio of the total assets of the issuer bank to the total assets of the largest bank in the year sample of the issuance date (Sironi (2003)).

The vector $X_{j}$ of bond specific characteristics includes: MATURITY ${ }_{j}$ which is the time left until the maturity of the issue, $A M O U N T_{j}$ which is the natural logarithm of the amount of the issue in euros (Morgan and Stiroh (2001), Sironi (2002), Sironi (2003) and Iannotta et al. (2011)). We expect respectively a positive and a negative sign. $S P L I T_{j}$ is a measure of disagreement between bond ratings of Moody's and Fitch rating agencies (Morgan (1998) and Morgan (2002)). As a measure of bank opacity, we expect a positive sign: a high split rating means that rating agencies quite disagree in their notation, which can be interpreted as a signal for relative bank opacity.

RISK may be alternatively a measure of the bond risk or the bank risk: $\operatorname{RATINGBOND}_{j}$, the average of available bond ratings for each bond at each date; $R A T I N G T R A D_{i(j), t(j)}$ the average of the issuer traditional ratings from Moody's and Fitch, RATINGSOLID ${ }_{i(j), t(j)}$ the average of bank individual/financial ratings and, at last, $R T O T_{i(j), t(j)}$ the bank total portfolio risk. In all case, we expect a positive sign as a higher rating corresponds, by convention, to a higher risk (Sironi (2003) and Iannotta et $a l .(2011))$.

At last we control for some additional variables $Z_{t(j)}$ that may affect the bond spread. As the bond spread may vary over the business cycle, we add a $C Y C L E_{t(j)}$ variable which captures the influence of economic conditions see Evanoff et al. (2011). It was computed using a HP filter on the basis of the quarterly GDP index of the country of bank i. DUMCRISIS $S_{t(j)}$ is a dummy equals to 1 when the issuance date is either 2008, 2009, 2010 or 2011; 0 otherwise. As this dummy may capture the effects of financial crisis, we expect a positive sign. The vector of control variables also contains dummies ${ }^{13}$ : $\operatorname{DUMCOUNTRY}_{t(j)}$ and DUMCURRENCY $Y_{t(j)}$ see Flannery and Sorescu (1996), Sironi (2003) and Iannotta et al. (2011). These dummies control for constant differences across banks issuers such as cross-country variation and liquidity effects that may affect bond spreads.

\section{Regression results}

We estimate the coefficients of the independent variables presented in equation (2) by applying the generalized method of moments (GMM) estimator with heteroskedasticity - robust standard errors, White correction (see (Podpiera and Weill (2008)) ${ }^{14}$.

\footnotetext{
${ }^{13}$ Some dummies are dropped to avoid collinearity problem in the sample data.

${ }^{14} \mathrm{We}$ wondered about the exogeneity of variables that may be adjusted by managers in reaction to the level of spread (LEV, LIQDEP and RTOT). This problem of recursive causality will biased the OLS estimates. We undertook the Hausman test which is conclusive (this test is available upon request). To avoid endogeneity, we preferred to estimate the spread equation based on GMM estimator (see Arellano and Bond (1991)). Event though, we provide in Appendix A3 an estimation with the OLS method as robustness check. Results are similar.
} 
Table 7 reports coefficients of GMM regressions over the whole sample period 2001 - 2011. While estimating equation (2), we use different proxies of risk, which appear in the different columns.

\section{[Insert Table 7 around here]}

Concerning risk measures, the bond rating variable (column 3 ) is the only one significant. The sign is positive as we expected: when this variable increases, that is the mean bond rating downgrades, the level of bond spread increases. Our leverage ratio variable (LEV) has a positive and significant coefficient as expected. A higher leverage indicates a higher default risk, thus bondholders require a higher bond spread. The sign of the size variable (TAMAX) is also consistent with our expectation. Investors reward large bank as they consider these banks as less risky than small ones. MATURITY has a highly significant positive sign indicating that bondholders require a higher bond spread while time to redemption increases. The negative sign of the AMOUNT variable suggests that large bonds benefit from a liquidity effect (see Morgan and Stiroh (2001)). When the SPLIT variable is significant, it is associated with a positive sign. This suggests that a high disagreement between bond ratings is associated with a higher bond spread. Market investors penalize bank opaqueness. The CYCLE variable has a positive significant coefficient. This result is quite surprising as it suggests that during growth periods the spread increases. The liquidity ratio (LIQDEP) is negative when significant. Higher bank liquidity may improve banks safety and bondholders reward those banks by requiring a smaller spread. The dummy which identifies the financial crisis (DUMCRISIS) is positive and significant, indicating an increase of bond spreads during this period. Finally our risk-return efficiency score variable (SCORE) is negative and significant whatever specification is retained. This result seems to indicate that market investors discipline banks as the spread on bonds they issue increases when their risk-return inefficiency increases. The market reacts to banks' risk management, to banks' performance.

We further investigate our results by analyzing the determinants of bond spreads before and during the financial crisis. Results are reported Table 8.

\section{[Insert Table 8 around here]}

Our estimations here show an important result: market investors behave differently before and during the financial crisis. Indeed before the financial crisis, 2001-2007, the coefficient of the risk-return efficiency score is mostly positive and significant whereas during the financial crisis 2008-2011, it remains negative and significant. It seems like before 2008, market investors do not take into account the risk-return efficiency of banks into their discipline even going to reward them for being inefficient. Our results could indicate that bondholders were not sensitive to the risk management of banks before the financial crisis. They could even suggest that bondholders prefer risk-taking profile. On the 
contrary, after 2008 , that is during the financial crisis, we find that when the risk-return efficiency decreases, the level of spread required increases, and we also find that an increase in the risk taken is penalized by a higher spread. In other words, market discipline seems to be effective during the financial crisis but not before.

To further analyze this result, we also separate our sample depending on economic condition: we consider on the one hand sound economic period (relative high growth period in Europe, 2001, 20042007) and on the other hand distressed economic period (2002-2003, 2008-2011). Results are shown in Appendix A4. Our findings corroborate and even strengthen our previous results: market discipline, appreciated by the risk-return efficiency score and the risk measure, is effective during distressed periods but not during economic sound ones.

\section{Conclusion}

Market discipline is an important tool of prudential supervision especially as the European banking system become more complex. Supervisors incorporate bank market signal in order to reinforce and enhance their indirect influence on the level of bank risk. Previous studies have found that bondholders are able to distinguish between different bank risk profiles and are able to discipline bank risk-taking by requiring a higher bond spread when the level of risk is excessive. None of these studies take into account the impact of risk management on bond spreads. In this paper we investigate whether market actors penalize banks that not optimally manage their risks: not only the level of risk matters, but also its management. This is the reason why we consider both risk and return and the efficiency of this couple to study market discipline. Our research question is then to examine how the risk-return efficiency affects bank financial cost measured through the spread at issuance of unsecured bonds.

To answer this question we calculate a risk-return efficiency score thanks to a parametric efficient frontier developed by Battese and Coelli (1993). We then integrate it as a determinant of the bond spread equation instead of considering profitability and risk components independently. Our results show over the sample period that a lower risk-return efficiency score is associated with a higher bond spread. Market actors may distinguish banks' performance in their management of risk and penalize the inefficient one by requiring a higher cost of funding. But while deepening our results, we show that this result does not hold before the financial crisis. They even suggest that market investors tend to prefer risk-taking banks, and charge lower bond spreads during sound economic period. On the contrary, market discipline becomes effective during distressed economic period: bondholders require higher bond spreads from more risky banks and more risk-return inefficient ones. 
Table 1: Number of banks and issues by country

\begin{tabular}{l||cc||ccc|}
\hline $\begin{array}{l}\text { Geographic } \\
\text { country }\end{array}$ & $\begin{array}{c}\text { Panel A : 166 banks (1996-2011) } \\
\text { Number of } \\
\text { banks }\end{array}$ & $\begin{array}{c}\text { Average total assets } \\
(\boldsymbol{€} \text { million) }\end{array}$ & $\begin{array}{c}\text { Panel B : 47 banks (1585 bonds, 2001-2011) } \\
\text { Number of } \\
\text { banks }\end{array}$ & $\begin{array}{c}\text { Number } \\
\text { of issues }\end{array}$ & $\begin{array}{c}\text { Average total assets } \\
(\boldsymbol{€} \text { million) }\end{array}$ \\
\hline AUSTRIA & 5 & $48,448.05$ & 2 & 63 & $16.415,81$ \\
BELGIUM & 1 & 843.70 & 0 & 0 & - \\
BRITAIN & 9 & $78,320.55$ & 5 & 54 & $137,969.68$ \\
DENMARK & 19 & $20,538.28$ & 3 & 119 & $357,401.14$ \\
FRANCE & 20 & $184,678.73$ & 6 & 242 & $1,125,982.00$ \\
GERMANY & 20 & $203,113.87$ & 8 & 564 & $646,967.75$ \\
GREECE & 15 & $20,653.09$ & 0 & 0 & - \\
IRELAND & 3 & $83,938.82$ & 3 & 198 & $130,267.29$ \\
ITALY & 38 & $59,246.76$ & 7 & 151 & $603,124.95$ \\
LUXEMBOURG & 4 & $29,712.92$ & 2 & 17 & $55,449.49$ \\
NETHERLANDS & 4 & $186,500.70$ & 2 & 40 & $26,357.49$ \\
PORTUGAL & 5 & $43,332.93$ & 5 & 17 & $89,651.82$ \\
SPAIN & 17 & $89,798.30$ & 3 & 111 & $210,020.17$ \\
SWEDEN & 6 & $88,589.54$ & $\mathbf{4 7}$ & $\mathbf{1 5 8 5}$ & $\mathbf{5 2 9 , 9 5 5 . 3 6}$
\end{tabular}

The average total assets are expressed in million euros. This is the average of bank total assets resident in each country over the considered period. Source: Authors' calculation using data from Bankscope and Bloomberg.

Table 2: Summary characteristics on bond issues per year (2001-2011)

\begin{tabular}{|c|c|c|c|c|c|c|c|c|}
\hline \multicolumn{9}{|c|}{ Panel B : 1585 bonds } \\
\hline \multirow[b]{2}{*}{$\begin{array}{l}\text { Issue } \\
\text { Year }\end{array}$} & \multirow[b]{2}{*}{$\begin{array}{l}\text { Number } \\
\text { of issues }\end{array}$} & \multicolumn{2}{|c|}{ Spread } & \multirow{2}{*}{$\begin{array}{c}\text { Mean } \\
\text { Maturity } \\
\text { (years) }\end{array}$} & \multirow{2}{*}{$\begin{array}{c}\text { Mean } \\
\text { Amount of } \\
\text { issue } \\
(€ \text { billion })\end{array}$} & \multirow{2}{*}{$\begin{array}{l}\text { Average } \\
\text { ISSUE } \\
\text { traditional } \\
\text { rating }\end{array}$} & \multirow{2}{*}{$\begin{array}{l}\text { Average } \\
\text { ISSUER } \\
\text { traditional } \\
\text { rating }\end{array}$} & \multirow{2}{*}{$\begin{array}{l}\text { Average } \\
\text { ISSUER } \\
\text { financial } \\
\text { strength rating }\end{array}$} \\
\hline & & Mean & $\begin{array}{l}\text { Std. } \\
\text { Dev. }\end{array}$ & & & & & \\
\hline 2001 & 98 & 117.01 & 186.04 & 6.24 & $1,795.30$ & 4.28 & 4.10 & 5.22 \\
\hline 2002 & 120 & 96.94 & 177.02 & 4.73 & 311.48 & 4.74 & 4.68 & 6.03 \\
\hline 2003 & 107 & 45.84 & 108.71 & 4.54 & 132.96 & 5.00 & 4.71 & 5.87 \\
\hline 2004 & 163 & 12.71 & 97.26 & 3.96 & 325.28 & 4.52 & 4.50 & 5.79 \\
\hline 2005 & 140 & 29.27 & 144.45 & 4.55 & 514.28 & 4.56 & 4.54 & 5.09 \\
\hline 2006 & 120 & 96.56 & 179.09 & 3.40 & 313.58 & 4.86 & 4.71 & 5.16 \\
\hline 2007 & 219 & 69.04 & 166.34 & 3.29 & $1,674.97$ & 4.05 & 4.04 & 5.48 \\
\hline 2008 & 185 & 109.99 & 117.07 & 4.10 & 665.37 & 3.85 & 4.39 & 6.29 \\
\hline 2009 & 230 & 125.92 & 112.13 & 3.61 & 832.48 & 3.21 & 4.76 & 7.17 \\
\hline 2010 & 113 & 126.41 & 131.29 & 5.77 & 890.58 & 4.68 & 5.63 & 7.32 \\
\hline 2011 & 90 & 122.81 & 102.83 & 4.54 & $1,047.11$ & 5.21 & 5.45 & 6.76 \\
\hline Total & 1585 & 86.59 & 138.38 & 4.43 & 498.25 & 4.45 & 4.68 & 6.01 \\
\hline
\end{tabular}

SPREAD is the difference in basis point between the bond yield at issuance and the yield of a same currency and maturity Treasury bond. All statistics are calculated at issuance. Our sample includes 1585 bonds issued by 47 different European banks. MATURITY is the mean number of years until the bond redemption. AMOUNT of bond is expressed in billion Euros. Average ISSUE traditional rating is the mean of bond ratings between numerical value of Moody's, Fitch and Standard's \& Poors traditional ratings as shown in Appendix A1. Average ISSUER traditional rating is a comparable measure applied to banks. Average ISSUER financial strength rating is the mean rating between numerical value of Fitch IBCA individual rating and Moody's bank financial strength rating. 
Table 3: Summary of stochastic frontier estimates parameters (panel A sample, 1996-2011)

\begin{tabular}{|c|c|c|c|c|c|}
\hline & Frontier equation & $\begin{array}{l}\text { Nb. } \\
\text { Obs. }\end{array}$ & $\begin{array}{c}\text { Log } \\
\text { Likelihood }\end{array}$ & $\gamma$ & $\sigma^{2}$ \\
\hline $1996-2001$ & $\begin{array}{cc}\mathrm{ROA}=0.58^{* * *}+ & 0.23^{* * *} . \mathrm{RTOT} \\
(0.00) & (0.00)\end{array}$ & 630 & -861.43 & $\begin{array}{l}0.61 * * * \\
(0.00)\end{array}$ & $\begin{array}{l}1.51^{* * * *} \\
(0.00)\end{array}$ \\
\hline $1996-2002$ & $\begin{array}{c}\mathrm{ROA}=0.65^{* * *}+0.18^{* * *} . \mathrm{RTOT} \\
(0.00) \quad(0.00)\end{array}$ & 743 & $-1,009.21$ & $\begin{array}{l}0.66 * * * \\
(0.00)\end{array}$ & $\begin{array}{l}1.58^{* * * *} \\
(0.00)\end{array}$ \\
\hline $1996-2003$ & $\begin{array}{c}\mathrm{ROA}=0.70^{* * *}+0.15^{* * *} . \mathrm{RTOT} \\
(0.00) \quad(0.00)\end{array}$ & 853 & $-1,166.45$ & $\begin{array}{l}0.63 * * * \\
(0.00)\end{array}$ & $\begin{array}{l}1.55^{* * *} \\
(0.00)\end{array}$ \\
\hline $1996-2004$ & $\begin{array}{c}\text { ROA }=0.74 * * *+0.13 * * * . \text { RTOT } \\
(0.00) \quad(0.00)\end{array}$ & 960 & $-1,321.45$ & $\begin{array}{l}0.59 * * * \\
(0.00)\end{array}$ & $\begin{array}{l}1.51^{* * *} \\
(0.00)\end{array}$ \\
\hline $1996-2005$ & $\begin{array}{c}\mathrm{ROA}=0.74 * * *+0.12 * * * \mathrm{RTOT} \\
(0.00) \quad(0.00)\end{array}$ & 1,068 & $-1,481.00$ & $\begin{array}{l}0.53 * * * \\
(0.00)\end{array}$ & $\begin{array}{l}1.46^{* * * *} \\
(0.00)\end{array}$ \\
\hline $1996-2006$ & $\begin{array}{c}\mathrm{ROA}=0.71^{* * *}+0.13^{* * *} . \mathrm{RTOT} \\
(0.00) \quad(0.00)\end{array}$ & 1,174 & $-1,637.30$ & $\begin{array}{l}0.48^{* * *} \\
(0.00) \\
\end{array}$ & $\begin{array}{l}1.40^{* * *} \\
(0.00)\end{array}$ \\
\hline $1996-2007$ & $\begin{array}{c}\mathrm{ROA}=0.74 * * *+0.10^{* * *} . \mathrm{RTOT} \\
(0.00) \quad(0.00)\end{array}$ & 1,276 & $-1,785.27$ & $\begin{array}{l}0.47 * * * \\
(0.00)\end{array}$ & $\begin{array}{l}1.38^{* * * *} \\
(0.00)\end{array}$ \\
\hline $1996-2008$ & $\begin{array}{c}\mathrm{ROA}=0.76^{* * *}+0.08^{* * *} . \mathrm{RTOT} \\
(0.00) \quad(0.00)\end{array}$ & 1,374 & $-1,925.90$ & $\begin{array}{l}0.45 * * * \\
(0.00)\end{array}$ & $\begin{array}{l}1.37 * * * \\
(0.00)\end{array}$ \\
\hline $1996-2009$ & $\begin{array}{c}\text { ROA }=0.87 * * *+0.00 . \text { RTOT } \\
(0.00)\end{array}$ & 1,464 & $-2,057.10$ & $\begin{array}{l}0.42 * * * \\
(0.00)\end{array}$ & $\begin{array}{l}1.34 * * * \\
(0.00)\end{array}$ \\
\hline $1996-2010$ & $\begin{array}{cc}\text { ROA }=0.91 * * * & -0.03 . R T O T \\
(0.00) & (0.23)\end{array}$ & 1,547 & $-2,174.02$ & $\begin{array}{l}0.41 * * * \\
(0.00)\end{array}$ & $\begin{array}{l}1.32 * * * \\
(0.00)\end{array}$ \\
\hline $1996-2011$ & $\begin{array}{cc}\text { ROA }=0.91 * * * & \text { 0.03.RTOT } \\
(0.00) & (0.22)\end{array}$ & 1,552 & $-2,181.05$ & $\begin{array}{l}0.41 * * * \\
(0.00)\end{array}$ & $\begin{array}{l}1.32 * * * \\
(0.00)\end{array}$ \\
\hline
\end{tabular}

P-values are shown in parentheses. ${ }^{* *}, * *, *$ indicate significance at the $1 \%, 5 \%, 10 \%$ levels respectively. $\gamma$ is equal to $\sigma^{2} /\left(\sigma_{v}^{2}+\sigma^{2}\right)$ and $\sigma^{2}$ is the variance of the inefficiency component $u_{i t}$

Table 4: Mean efficiency score and corrected score (panel A sample, 2001-2011)

\begin{tabular}{|c||c|c|c|}
\hline \multicolumn{1}{c||}{} & \multicolumn{2}{c|}{ Mean Efficiency } & \multirow{2}{*}{ Nb. Obs. } \\
\cline { 2 - 3 } & "Normal" Score & "Corrected" Score & Nb. \\
& ROA-RTOT & ROA-RTOT & 115 \\
\hline $\mathbf{2 0 0 1}$ & 0.53 & 0.53 & 113 \\
$\mathbf{2 0 0 2}$ & 0.52 & 0.52 & 110 \\
$\mathbf{2 0 0 3}$ & 0.54 & 0.54 & 107 \\
$\mathbf{2 0 0 4}$ & 0.56 & 0.56 & 108 \\
$\mathbf{2 0 0 5}$ & 0.59 & 0.59 & 106 \\
$\mathbf{2 0 0 6}$ & 0.61 & 0.61 & 102 \\
$\mathbf{2 0 0 7}$ & 0.60 & 0.60 & 98 \\
$\mathbf{2 0 0 8}$ & 0.56 & 0.56 & 90 \\
$\mathbf{2 0 0 9}$ & 0.58 & 0.15 & 5 \\
$\mathbf{2 0 1 0}$ & 0.59 & 0.09 & 1037 \\
$\mathbf{2 0 1 1}$ & 0.62 & 0.49 & 5 \\
\hline Total & 0.56 & 0.48 & \\
\hline
\end{tabular}

"Normal" score and "corrected" score only differ for 2009, 2010 and 2011. Here, to calculate the "normal" score, we refer to a $B P F$ with a negative slop whereas the "corrected" score is computed starting from the $1996-2008 B P F$, the last $B P F$ with a positive and significant relationship between risk and return.

Table 5: Descriptive statistics for variables used to estimate the optimal frontier and for the risk-return efficiency score (panel A sample, 1996 - 2011)

\begin{tabular}{|l||c|c|c|c|c|}
\hline \multicolumn{1}{c|}{ Name } & $\begin{array}{c}\text { Mean } \\
\%\end{array}$ & $\begin{array}{c}\text { Stand. Dev. } \\
\mathbf{\%}\end{array}$ & $\begin{array}{c}\text { Minimum } \\
\%\end{array}$ & $\begin{array}{c}\text { Maximum } \\
\%\end{array}$ & Nb. Obs. \\
\hline ROA & 0.86 & 3.36 & -37.34 & 29.32 & 1,861 \\
\hline RTOT & 2.22 & 1.58 & 0.02 & 19.59 & 1,833 \\
\hline SCORE ROA-RTOT & 48.80 & 19.04 & 0.00 & 100.00 & 1,037 \\
\hline
\end{tabular}

This table presents the descriptive statistics for the variables used frontier equation. We clean ROA and RTOT, by removing extreme observations and then lost $1 \%$ of observations. ROA is the return on average assets. RTOT is the bank's portfolio risk. SCORE ROA - RTOT is the previous "corrected" score which measure the relative position of a bank compared to the $B P F$ of bank risk-return efficiency. 
Table 6: Descriptive statistics for variables used in equation 2 (panel B sample, 2001-2011)

\begin{tabular}{|c|c|c|c|c|c|c|}
\hline Name & Mean & Stand. Dev. & Min. & Max. & Nb. Obs. & Expected sign \\
\hline SPREAD & 85.50 & 145.59 & -405.06 & 562.79 & 1,585 & \\
\hline SCORE ROA - RTOT (\%) & 44.69 & 19.36 & 1.32 & 63.04 & 1,301 & - \\
\hline RATINGBOND & 4.30 & 1.37 & 1.00 & 11.2 & 1,585 & + \\
\hline RATINGTRAD & 4.62 & 1.39 & 2.00 & 13.70 & 1,511 & + \\
\hline RATINGSOLID & 6.04 & 2.03 & 2.75 & 13.00 & 1,552 & + \\
\hline RTOT (\%) & 2.45 & 1.71 & 0.06 & 12.97 & 1,387 & + \\
\hline LIQDEP (\%) & 52.55 & 34.27 & 4.56 & 205.23 & 1,477 & - \\
\hline LEV & 25.79 & 9.62 & 7.20 & 67.57 & 1,477 & + \\
\hline TAMAX (\%) & 36.53 & 32.76 & 0.00 & 1.00 & 1,477 & - \\
\hline MATURITY & 4.24 & 3.29 & 0.25 & 32.93 & 1,585 & + \\
\hline AMOUNT & 18.00 & 2.22 & 12.15 & 25.27 & 1,585 & - \\
\hline SPLIT (\%) & 0.91 & 0.89 & 0.00 & 6.2 & 1,181 & + \\
\hline CYCLE & -0.48 & 5.28 & -18.84 & 12.52 & 1,457 & - \\
\hline
\end{tabular}

SPREAD is the difference in basis point between the bond yield at issuance and the yield of a same currency. SCORE is computed with ROA as a measure of bank profitability and RTOT, bank portfolio total risk as a measure of bank risk. RATINGBOND is the average of available bond ratings for each bond at each date. RATINGTRAD is the average of the issuer traditional ratings from Moody's and Fitch. RATINGSOLID is the average of bank individual/financial ratings. LIQDEP is the ratio of liquid assets to customer deposits and short term funding. LEV is the total liabilities to total equity ratio. TAMAX is the issuing bank's total assets to the total assets of the largest bank in the sample in the year of the issuance date. MATURITY is the number of years until the bond redemption. AMOUNT is the natural logarithm of amount of issue in euros. SPLIT is the disagreement between Moody's and Fitch bonds ratings. CYCLE is extract from the GDP with a HP filter.

Table 7: Bond spread equation (whole sample period, 1,545 issues by 47 banks, GMM estimator) Model : $S P R E A D_{j}=\alpha+\beta S C O R E_{i(j), t(j)}+\gamma Y_{i(j), t(j)}+\theta X_{j}+\tau Z_{t(j)}+\varepsilon_{j}$

\begin{tabular}{|c|c|c|c|c|c|c|c|}
\hline \multicolumn{8}{|c|}{ (2001-2011, GMM estimator) } \\
\hline Variables $\quad$ Risk: & \multicolumn{3}{|c|}{ RATINGBOND } & $\begin{array}{l}\text { RATING } \\
\text { TRAD }\end{array}$ & $\begin{array}{l}\text { RATING } \\
\text { SOLID }\end{array}$ & RTOT & Without RISK \\
\hline SCORE & $\begin{array}{c}-234.39 * * * \\
(0.00)\end{array}$ & $\begin{array}{c}-155.07 * * * \\
(0.00)\end{array}$ & $\begin{array}{c}-80.65^{*} \\
(0.07)\end{array}$ & $\begin{array}{c}-145.74 * * * \\
(0.00)\end{array}$ & $\begin{array}{c}-119.96 * * \\
(0.02)\end{array}$ & $\begin{array}{c}-98.71 * * \\
(0.05)\end{array}$ & $\begin{array}{c}-120.99 * * * \\
(0.01)\end{array}$ \\
\hline RISK & $\begin{array}{l}-6.77 \\
(0.16)\end{array}$ & $\begin{array}{l}-1.54 \\
(0.77)\end{array}$ & $\begin{array}{c}10.68 * * * \\
(0.00)\end{array}$ & $\begin{array}{l}-3.37 \\
(0.40)\end{array}$ & $\begin{array}{l}1.43 \\
(0.51)\end{array}$ & $\begin{array}{l}4.86 \\
(0.39)\end{array}$ & - \\
\hline LIQDEP & $\begin{array}{c}-39.39 \\
(0.12)\end{array}$ & $\begin{array}{c}-48.40 * * \\
(0.06)\end{array}$ & $\begin{array}{l}-7.06 \\
(0.74)\end{array}$ & $\begin{array}{l}-0.51 \\
(0.98)\end{array}$ & $\begin{array}{l}-6.21 \\
(0.78)\end{array}$ & $\begin{array}{l}-2.98 \\
(0.89)\end{array}$ & $\begin{array}{l}-3.68 \\
(0.86)\end{array}$ \\
\hline LEV & $\begin{array}{c}1.85 * * * \\
(0.00)\end{array}$ & $\begin{array}{l}1.85 * * * \\
(0.00)\end{array}$ & $\begin{array}{l}1.98 * * * \\
(0.00)\end{array}$ & $\begin{array}{c}1.95 * * * \\
(0.00)\end{array}$ & $\begin{array}{l}1.92 * * * \\
(0.00)\end{array}$ & $\begin{array}{c}1.86 * * * \\
(0.00)\end{array}$ & $\begin{array}{l}1.88 * * * * \\
(0.00)\end{array}$ \\
\hline TAMAX & $\begin{array}{c}-82.34 * * * \\
(0.00)\end{array}$ & $\begin{array}{c}-67.71 * * * \\
(0.01)\end{array}$ & $\begin{array}{c}-53.33 * * \\
(0.02)\end{array}$ & $\begin{array}{c}-82.03 * * * \\
(0.00)\end{array}$ & $\begin{array}{c}-65.86 * * * \\
(0.00)\end{array}$ & $\begin{array}{l}-74.57 * * * \\
\quad(0.00)\end{array}$ & $\begin{array}{c}-70.93 * * * \\
(0.00)\end{array}$ \\
\hline MATURITY & $\begin{array}{c}2.48 * * \\
(0.05)\end{array}$ & $\begin{array}{l}2.28 * \\
(0.06)\end{array}$ & $\begin{array}{c}3.00 * * \\
(0.02)\end{array}$ & $\begin{array}{c}3.30 * * * \\
(0.01)\end{array}$ & $\begin{array}{c}3.36 * * * \\
(0.00)\end{array}$ & $\begin{array}{c}3.46 * * * \\
(0.00)\end{array}$ & $\begin{array}{c}3.60 * * * \\
(0.00)\end{array}$ \\
\hline AMOUNT & $\begin{array}{c}-9.47 * * * \\
(0.00)\end{array}$ & $\begin{array}{l}-9.69 * * * \\
(0.00)\end{array}$ & $\begin{array}{c}2.77 \\
(0.12)\end{array}$ & $\begin{array}{c}1.81 \\
(0.31)\end{array}$ & $\begin{array}{c}1.56 \\
(0.38)\end{array}$ & $\begin{array}{c}1.53 \\
(0.37)\end{array}$ & $\begin{array}{c}2.04 \\
(0.25)\end{array}$ \\
\hline SPLIT & $\begin{array}{l}12.75 * * \\
(0.03)\end{array}$ & $\begin{array}{c}8.39 \\
(0.16)\end{array}$ & $\begin{array}{c}4.08 \\
(0.40)\end{array}$ & $\begin{array}{c}6.97 \\
(0.14)\end{array}$ & $\begin{array}{c}7.23 \\
(0.12)\end{array}$ & $\begin{array}{l}7.87 * \\
(0.10)\end{array}$ & $\begin{array}{c}7.09 \\
(0.13)\end{array}$ \\
\hline CYCLE & $\begin{array}{l}9.48 * * * \\
(0.00)\end{array}$ & $\begin{array}{l}7.28 * * * \\
(0.00)\end{array}$ & $\begin{array}{l}3.75 * * * \\
(0.00)\end{array}$ & $\begin{array}{c}5.20 * * * \\
(0.00)\end{array}$ & $\begin{array}{c}4.56 * * * \\
(0.00)\end{array}$ & $\begin{array}{c}4.67 * * * \\
(0.00)\end{array}$ & $\begin{array}{c}4.62 * * * \\
(0.00)\end{array}$ \\
\hline DUMCRISIS & - & $\begin{array}{c}44.52 * * * \\
(0.00)\end{array}$ & $\begin{array}{c}66.50 * * * \\
(0.00)\end{array}$ & $\begin{array}{c}48.19 * * * \\
(0.00)\end{array}$ & $\begin{array}{c}50.413 * * * \\
(0.00)\end{array}$ & $\begin{array}{l}46.58 * * * \\
(0.00)\end{array}$ & $\begin{array}{l}52.54 * * * \\
(0.00)\end{array}$ \\
\hline $\begin{array}{l}\text { DUMCOUNTRY } \\
\text { DUMCURRENCY }\end{array}$ & $\begin{array}{l}\mathrm{NO} \\
\mathrm{NO}\end{array}$ & $\begin{array}{l}\mathrm{NO} \\
\mathrm{NO}\end{array}$ & $\begin{array}{l}\text { YES } \\
\text { YES }\end{array}$ & $\begin{array}{l}\text { YES } \\
\text { YES }\end{array}$ & $\begin{array}{l}\text { YES } \\
\text { YES }\end{array}$ & $\begin{array}{l}\text { YES } \\
\text { YES }\end{array}$ & $\begin{array}{l}\text { YES } \\
\text { YES }\end{array}$ \\
\hline $\begin{array}{l}\text { Obs. } \\
\mathbf{R}^{2}\end{array}$ & $\begin{array}{l}857 \\
0.17\end{array}$ & $\begin{array}{l}857 \\
0.18\end{array}$ & $\begin{array}{l}857 \\
0.55\end{array}$ & $\begin{array}{r}848 \\
0.55\end{array}$ & $\begin{array}{l}852 \\
0.55\end{array}$ & $\begin{array}{l}852 \\
0.55\end{array}$ & $\begin{array}{l}857 \\
0.55\end{array}$ \\
\hline
\end{tabular}

$\mathrm{P}$-values are shown in parentheses. $* * *, * *, *$ indicate significance at the $1 \%, 5 \%, 10 \%$ levels respectively. SPREAD is the difference in basis point between the bond yield at issuance and the yield of a same currency. SCORE is computed with ROA as a measure of bank profitability and RTOT, bank portfolio total risk as a measure of bank risk. RATINGBOND is the average of available bond ratings for each bond at each date. RATINGTRAD is the average of the issuer traditional ratings from Moody's and Fitch. RATINGSOLID is the average of bank individual/financial ratings. LIQDEP is the ratio of liquid assets to customer deposits and short term funding. LEV is the total liabilities to total equity ratio. TAMAX is the issuing bank's total assets to the total assets of the largest bank in the sample in the year of the issuance date. MATURITY is the number of years until the bond redemption. AMOUNT is the natural logarithm of amount of issue in euros. SPLIT is the disagreement between Moody's and Fitch bonds ratings. CYCLE is extract from the GDP with a HP filter. DUMCRISIS is a dummy equals to 1 when the bond is issued during the financial crisis; 0 otherwise. 
Table 8: Bond spread equation (sub-sample periods 2001-2007 and 2008-2011, GMM estimator) Model : $S P R E A D_{j}=\alpha+\beta S C O R E_{i(j), t(j)}+\gamma Y_{i(j), t(j)}+\theta X_{j}+\tau Z_{t(j)}+\varepsilon_{j}$

\begin{tabular}{|c|c|c|c|c|c|c|}
\hline \multicolumn{7}{|c|}{ (2001 - 2007, GMM estimator) } \\
\hline Variables & \multicolumn{2}{|c|}{ RATINGBOND } & $\begin{array}{c}\text { RATING } \\
\text { TRAD }\end{array}$ & $\begin{array}{c}\text { RATING } \\
\text { SOLID }\end{array}$ & RTOT & Without RISK \\
\hline SCORE & $\begin{array}{c}683.18 * * * \\
(0.00)\end{array}$ & $\begin{array}{c}416.98 * * \\
(0.02)\end{array}$ & $\begin{array}{c}366.02 * \\
(0.07)\end{array}$ & $\begin{array}{c}436.96 * * \\
(0.03)\end{array}$ & $\begin{array}{l}34.30 \\
(0.87)\end{array}$ & $\begin{array}{c}318.83^{*} \\
(0.10)\end{array}$ \\
\hline RISK & $\begin{array}{l}-5.69 \\
(0.46)\end{array}$ & $\begin{array}{l}6.056 \\
(0.25)\end{array}$ & $\begin{array}{c}0.46 \\
(0.94)\end{array}$ & $\begin{array}{l}3.01 \\
(0.26)\end{array}$ & $\begin{array}{c}-26.33^{* *} \\
(0.03)\end{array}$ & - \\
\hline LIQDEP & $\begin{array}{l}-88.88 * * * \\
(0.00)\end{array}$ & $\begin{array}{c}-15.41 \\
(0.54)\end{array}$ & $\begin{array}{c}-15.79 \\
(0.55)\end{array}$ & $\begin{array}{l}-23.56 \\
(0.38)\end{array}$ & $\begin{array}{l}-0.96 \\
(0.96)\end{array}$ & $\begin{array}{c}-14.48 \\
(0.57)\end{array}$ \\
\hline LEV & $\begin{array}{c}2.61 * * * \\
(0.00)\end{array}$ & $\begin{array}{l}0.41 \\
(0.62)\end{array}$ & $\begin{array}{c}0.71 \\
(0.42)\end{array}$ & $\begin{array}{c}0.47 \\
(0.62)\end{array}$ & $\begin{array}{c}1.30 \\
(0.12)\end{array}$ & $\begin{array}{c}0.71 \\
(0.41)\end{array}$ \\
\hline TAMAX & $\begin{array}{c}-22.10 \\
(0.55)\end{array}$ & $\begin{array}{c}-24.85 \\
(0.34)\end{array}$ & $\begin{array}{c}-33.92 \\
(0.28)\end{array}$ & $\begin{array}{c}-17.93 \\
(0.58)\end{array}$ & $\begin{array}{c}-42.92 * * \\
(0.05)\end{array}$ & $\begin{array}{c}-36.22 \\
(0.16)\end{array}$ \\
\hline MATURITY & $\begin{array}{l}2.92 * \\
(0.07)\end{array}$ & $\begin{array}{l}4.14 * * * \\
(0.00)\end{array}$ & $\begin{array}{l}3.65^{* *} * \\
(0.02)\end{array}$ & $\begin{array}{l}3.80 * * * \\
(0.00)\end{array}$ & $\begin{array}{c}3.17 * * \\
(0.03)\end{array}$ & $\begin{array}{c}4.33 * * * \\
(0.00)\end{array}$ \\
\hline AMOUNT & $\begin{array}{c}-15.35 * * * \\
(0.00)\end{array}$ & $\begin{array}{c}0.77 \\
(0.73)\end{array}$ & $\begin{array}{c}0.10 \\
(0.96)\end{array}$ & $\begin{array}{c}0.05 \\
(0.98)\end{array}$ & $\begin{array}{c}0.92 \\
(0.66)\end{array}$ & $\begin{array}{c}0.54 \\
(0.82)\end{array}$ \\
\hline SPLIT & $\begin{array}{c}8.25 \\
(0.28)\end{array}$ & $\begin{array}{l}5.78 \\
(0.29)\end{array}$ & $\begin{array}{c}7.24 \\
(0.17)\end{array}$ & $\begin{array}{c}6.11 \\
(0.23)\end{array}$ & $\begin{array}{c}2.39 \\
(0.64)\end{array}$ & $\begin{array}{c}6.91 \\
(0.20)\end{array}$ \\
\hline CYCLE & $\begin{array}{c}13.97 * * * \\
(0.00)\end{array}$ & $\begin{array}{l}2.81 \\
(0.17\end{array}$ & $\begin{array}{l}2.95 \\
(0.15)\end{array}$ & $\begin{array}{l}2.55 \\
(0.22)\end{array}$ & $\begin{array}{c}4.07 * * \\
(0.05)\end{array}$ & $\begin{array}{l}2.68 \\
(0.19)\end{array}$ \\
\hline DUMCOUNTRY & $\mathrm{NO}$ & YES & YES & YES & YES & YES \\
\hline DUMCURRENCY & NO & YES & YES & YES & YES & YES \\
\hline Obs. & 561 & 561 & 553 & 560 & 560 & 561 \\
\hline $\mathbf{R}^{2}$ & 0.19 & 0.70 & 0.70 & 0.70 & 0.69 & 0.69 \\
\hline
\end{tabular}

\begin{tabular}{|c|c|c|c|c|c|c|}
\hline \multicolumn{7}{|c|}{ (2008 - 2011, GMM estimator) } \\
\hline Variables & \multicolumn{2}{|c|}{ RATINGBOND } & $\begin{array}{l}\text { RATING } \\
\text { TRAD }\end{array}$ & $\begin{array}{l}\text { RATING } \\
\text { SOLID }\end{array}$ & RTOT & Without RISK \\
\hline SCORE & $\begin{array}{c}-142.54 * * * \\
(0.01)\end{array}$ & $\begin{array}{l}-8.98 \\
(0.85)\end{array}$ & $\begin{array}{c}-100.62 * \\
(0.09)\end{array}$ & $\begin{array}{c}-96.14 \\
(0.13)\end{array}$ & $\begin{array}{c}-62.37 \\
(0.33)\end{array}$ & $\begin{array}{c}-103.93^{*} \\
(0.08)\end{array}$ \\
\hline RISK & $\begin{array}{c}25.65 * * * \\
(0.00)\end{array}$ & $\begin{array}{l}36.00 * * * \\
(0.00)\end{array}$ & $\begin{array}{c}1.68 \\
(0.79)\end{array}$ & $\begin{array}{l}5.55 \\
(0.26)\end{array}$ & $\begin{array}{l}11.27 \\
(0.20)\end{array}$ & - \\
\hline LIQDEP & $\begin{array}{c}-47.04 \\
(0.25)\end{array}$ & $\begin{array}{c}-52.21 \\
(0.17)\end{array}$ & $\begin{array}{c}-24.94 \\
(0.52)\end{array}$ & $\begin{array}{l}-31.50 \\
(0.40)\end{array}$ & $\begin{array}{c}-20.98 \\
(0.58)\end{array}$ & $\begin{array}{l}-25.36 \\
(0.52)\end{array}$ \\
\hline LEV & $\begin{array}{l}2.05 * * * \\
(0.00)\end{array}$ & $\begin{array}{l}4.54 * * * \\
(0.00)\end{array}$ & $\begin{array}{c}2.62 * * * \\
(0.01)\end{array}$ & $\begin{array}{c}2.49 * * \\
(0.02)\end{array}$ & $\begin{array}{l}1.80 * \\
(0.08)\end{array}$ & $\begin{array}{c}2.63 * * \\
(0.02)\end{array}$ \\
\hline TAMAX & $\begin{array}{l}35.28 \\
(0.35)\end{array}$ & $\begin{array}{l}-6.43 \\
(0.90)\end{array}$ & $\begin{array}{c}-50.44 \\
(0.35)\end{array}$ & $\begin{array}{c}-22.46 \\
(0.64)\end{array}$ & $\begin{array}{c}-37.81 \\
(0.44)\end{array}$ & $\begin{array}{c}-55.32 \\
(0.32)\end{array}$ \\
\hline MATURITY & $\begin{array}{c}1.01 \\
(0.61)\end{array}$ & $\begin{array}{c}2.56 \\
(0.21)\end{array}$ & $\begin{array}{c}4.92 * * \\
(0.03)\end{array}$ & $\begin{array}{c}5.06 * * \\
(0.04)\end{array}$ & $\begin{array}{c}5.11 * * \\
(0.04)\end{array}$ & $\begin{array}{c}4.85 * * \\
(0.03)\end{array}$ \\
\hline AMOUNT & $\begin{array}{l}-4.69 \\
(0.11)\end{array}$ & $\begin{array}{c}2.86 \\
(0.35)\end{array}$ & $\begin{array}{l}-0.06 \\
(0.98)\end{array}$ & $\begin{array}{l}-0.34 \\
(0.91)\end{array}$ & $\begin{array}{l}-0.74 \\
(0.82)\end{array}$ & $\begin{array}{c}0.18 \\
(0.95)\end{array}$ \\
\hline SPLIT & $\begin{array}{c}-32.95 * * * \\
(0.00)\end{array}$ & $\begin{array}{l}-37.54 * * * \\
(0.00)\end{array}$ & $\begin{array}{c}-12.61 \\
(0.16)\end{array}$ & $\begin{array}{c}-12.98 \\
(0.15)\end{array}$ & $\begin{array}{c}-13.19 \\
(0.15)\end{array}$ & $\begin{array}{c}-12.43 \\
(0.16)\end{array}$ \\
\hline CYCLE & $\begin{array}{c}5.14 * * * \\
(0.00)\end{array}$ & $\begin{array}{c}2.12 \\
(0.16) \\
0\end{array}$ & $\begin{array}{c}4.65 * * * \\
(0.00)\end{array}$ & $\begin{array}{c}4.80 * * * \\
(0.00)\end{array}$ & $\begin{array}{c}5.56 * * * \\
(0.00)\end{array}$ & $\begin{array}{c}4.76 * * * \\
(0.00)\end{array}$ \\
\hline DUMCOUNTRY & $\mathrm{NO}$ & YES & YES & YES & YES & YES \\
\hline DUMCURRENCY & NO & YES & YES & YES & YES & YES \\
\hline $\begin{array}{l}\text { Obs. } \\
\mathbf{R}^{2} \\
\end{array}$ & $\begin{array}{l}296 \\
0.15\end{array}$ & $\begin{array}{l}296 \\
0.33 \\
\end{array}$ & $\begin{array}{l}295 \\
0.26\end{array}$ & $\begin{array}{l}292 \\
0.27\end{array}$ & $\begin{array}{l}292 \\
0.28 \\
\end{array}$ & $\begin{array}{l}296 \\
0.26\end{array}$ \\
\hline
\end{tabular}

P-values are shown in parentheses. $* * *, * * *$ indicate significance at the $1 \%, 5 \%, 10 \%$ levels respectively. SPREAD is the difference in basis point between the bond yield at issuance and the yield of a same currency. SCORE is computed with ROA as a measure of bank profitability and RTOT, bank portfolio total risk as a measure of bank risk. RATINGBOND is the average of available bond ratings for each bond at each date. RATINGTRAD is the average of the issuer traditional ratings from Moody's and Fitch. RATINGSOLID is the average of bank individual/financial ratings. LIQDEP is the ratio of liquid assets to customer deposits and short term funding. LEV is the total liabilities to total equity ratio. TAMAX is the issuing bank's total assets to the total assets of the largest bank in the sample in the year of the issuance date. MATURITY is the number of years until the bond redemption. AMOUNT is the natural logarithm of amount of issue in euros. SPLIT is the disagreement between Moody's and Fitch bonds ratings. CYCLE is extract from the GDP with a HP filter. 


\section{REFERENCES}

Arellano, M., Bond, S., (1991). Some tests of specification for panel data: Monte Carlo evidence and an application to employment equations. Rev. Econ. Stud. 58, 277-297.

Baele, L., Bruyckere, V.D., Jonghe, O.D., and Vennet, R.V. (2011). Do Stock Markets Discipline US Bank Holding Companies: Just Monitoring, or Also Influencing? (Ghent - Working Paper)

Battese, G.E. and Coelli, T.J. (1993). A Stochastic Frontier Production Function Incorporating a Model for Technical Inefficiency Effects. Working Paper in Econometrics and Applied Statistics, No.69, Department of Econometrics, University of New England, Armidale, pp.22.

Bliss, R.R. \& Flannery M.J. (2002). Market discipline in the governance of U.S. bank holdings companies: Monitoring vs. influencing. European Finance Review, 6(3), 361-95.

Board of Governors of the Federal Reserve System, BGFRS (1999). Using subordinated debt as an instrument of market discipline. Staff Study No. 172, December

DeYoung, R., Flannery, M.J., Lang, W.W., and Sorescu, S.M. (2001-a). The Information Content of Bank Exam Ratings and Subordinated Debt Prices. Journal of Money, Credit and Banking 33, 900925.

DeYoung, R.E., Hughes, J.P., and Moon, C.-G. (2001-b). Efficient risk-taking and regulatory covenant enforcement in a deregulated banking industry. Journal of Economics and Business 53, 255-282.

Elton, E.J., Gruber, M.J., Agrawal, D., and Mann, C. (2001). Explaining the Rate Spread on Corporate Bonds. The Journal of Finance 56, 247-277.

Evanoff, D., and Wall, L. (2001). Subordinated Debt and Bank Capital Reform (Rochester, FRB Working Paper)

Evanoff, D.D., Jagtiani, J.A., and Nakata, T. (2011). Enhancing market discipline in banking: The role of subordinated debt in financial regulatory reform. Journal of Economics and Business 63, 1-22.

Flannery, M.J., and Sorescu, S.M. (1996). Evidence of Bank Market Discipline in Subordinated Debenture Yields: 1983- 1991. The Journal of Finance 51, 1347-1377.

Iannotta, G. (2008). Market Discipline in the Banking Industry: Evidence from Spread Dispersion. (CAREFIN - Working paper)

Iannotta, G., Nocera, G., and Resti, A. (2011). Do Investors Care About Credit Ratings? An Analysis Through the Cycle. SSRN eLibrary.

Jagtiani, J., Kaufman, G., and Lemieux, C. (2002). The Effect of Credit Risk on Bank and Bank Holding Company Bond Yields: Evidence from the Post-FDICIA Period. Journal of Financial Research 25, 559-575.

De Jonghe, O., Disli, M., and Schoors, K. (2012). Corporate Governance, Opaque Bank Activities, and Risk/Return Efficiency: Pre- and Post-Crisis Evidence from Turkey. Journal of Financial Services Research 41, 51-80. 
Morgan, D.P. (1998). Judging the risk of banks: what makes banks opaque? (Federal Reserve Bank of New York).

Morgan, D.P. (2002). Rating Banks: Risk and Uncertainty in an Opaque Industry. American Economic Review 92, 874-888.

Morgan, D.P., and Stiroh, K.J. (1999). Bond market discipline of banks: is the market tough enough? (Federal Reserve Bank of New York).

Morgan, D.P., and Stiroh, K.J. (2001). Market Discipline of Banks: The Asset Test. Journal of Financial Services Research 20, 195-208.

Pennacchi, G., and Iannotta, G. (2012). Bank Regulation, Credit Ratings, and Systematic Risk (Working paper)

Podpiera, J., and Weill, L. (2008). Bad luck or bad management? Emerging banking market experience. Journal of Financial Stability 4, 135-148.

Pop, A., and Pop, D. (2012). The Quality of Private Monitoring in European Banking: Completing the Picture (Granem - Working Paper)

Ronn, E.I., and Verma, A.K. (1987). A multi-attribute comparative evaluation of relative risk for a sample of banks. Journal of Banking \& Finance 11, 499-523.

Sironi, A. (2002). Strengthening banks' market discipline and leveling the playing field: Are the two compatible? Journal of Banking \& Finance 26, 1065-1091.

Sironi, A. (2003). Testing for Market Discipline in the European Banking Industry: Evidence from Subordinated Debt Issues. Journal of Money, Credit and Banking 35, 443-472. 


\section{APPENDIX}

Appendix A1: Ratings scales

These tables indicate the numerical scales for credit ratings of Moody's, Fitch and Standards \& Poor's (see Ronn and Verma (1987) and Pop and Pop (2012)). Bloomberg database provides outlook, we consider it in the ratings scale. If the outlook is positive, we subtract 0.2 to the numeric value. If the outlook is negative, we add 0.2 to the numeric value. If the outlook is neutral, the numeric value is unchanged.

\section{Traditional credit rating: Issuer and issue}

\begin{tabular}{|c|c|c|c|}
\hline $\begin{array}{c}\text { Cardinal } \\
\text { value }\end{array}$ & Moody's & Fitch & S\&P \\
\hline 1 & Aaa & AAA & AAA \\
\hline 2 & Aal & $\mathrm{AA}+$ & $\mathrm{AA}+$ \\
\hline 3 & $\mathrm{Aa} 2$ & AA & AA \\
\hline 4 & Aa3 & AA- & AA- \\
\hline 5 & $\mathrm{~A} 1$ & $\mathrm{~A}+$ & $\mathrm{A}+$ \\
\hline 6 & A2 & $\mathrm{A}$ & $\mathrm{A}$ \\
\hline 7 & A3 & A- & A- \\
\hline 8 & Baa1 & $\mathrm{BBB}+$ & $\mathrm{BBB}+$ \\
\hline 9 & Baa2 & $\mathrm{BBB}$ & BBB \\
\hline 10 & Baa3 & BBB- & BBB- \\
\hline 11 & Bal & $\mathrm{BB}+$ & $\mathrm{BB}+$ \\
\hline 12 & $\mathrm{Ba} 2$ & $\mathrm{BB}$ & $\mathrm{BB}$ \\
\hline 13 & $\mathrm{Ba} 3$ & BB- & BB- \\
\hline 14 & B1 & $\mathrm{B}+$ & $\mathrm{B}+$ \\
\hline 15 & $\mathrm{~B} 2$ & B & $\mathrm{B}$ \\
\hline 16 & B3 & B- & B- \\
\hline 17 & Caal & $\mathrm{CCC}+$ & $\mathrm{CCC}+$ \\
\hline 18 & $\mathrm{Caa} 2$ & $\mathrm{CCC}$ & $\mathrm{CCC}$ \\
\hline 19 & Caa3 & CCC- & CCC- \\
\hline 20 & $\mathrm{Ca}$ & $\mathrm{CC}$ & $\mathrm{CC}$ \\
\hline \multirow[t]{2}{*}{21} & $\mathrm{C}$ & $\mathrm{C}$ & $\mathrm{C}$ \\
\hline & \multicolumn{3}{|c|}{ Outlook } \\
\hline-0.2 & \multirow{3}{*}{\multicolumn{3}{|c|}{$\begin{array}{c}\text { Positive } \\
\text { Neutral } \\
\text { Negative }\end{array}$}} \\
\hline $\mathbf{0}$ & & & \\
\hline 0.2 & & & \\
\hline
\end{tabular}

2. Financial strength rating : Issuer

\begin{tabular}{|c|c|c|c|}
\hline $\begin{array}{l}\text { Cardinal } \\
\text { value }\end{array}$ & MBFS & $\begin{array}{c}\text { Cardinal } \\
\text { value }\end{array}$ & FBIR \\
\hline 1 & A & 1 & A \\
\hline \multirow[t]{2}{*}{2} & A- & & \\
\hline & & 2,5 & $\mathrm{~A} / \mathrm{B}$ \\
\hline 3 & $\mathrm{~B}+$ & & \\
\hline 4 & $\mathrm{~B}$ & 4 & B \\
\hline \multirow[t]{2}{*}{5} & B- & & \\
\hline & & 5,5 & $\mathrm{~B} / \mathrm{C}$ \\
\hline 6 & $\mathrm{C}+$ & & \\
\hline 7 & $\mathrm{C}$ & 7 & $\mathrm{C}$ \\
\hline \multirow[t]{2}{*}{8} & $\mathrm{C}-$ & & \\
\hline & & 8,5 & $\mathrm{C} / \mathrm{D}$ \\
\hline 9 & $\mathrm{D}+$ & & \\
\hline 10 & $\mathrm{D}$ & 10 & $\mathrm{D}$ \\
\hline \multirow[t]{2}{*}{11} & D- & & \\
\hline & & 11,5 & $\mathrm{D} / \mathrm{E}$ \\
\hline 12 & $\mathrm{E}+$ & & \\
\hline \multirow[t]{2}{*}{13} & $\mathrm{E}$ & 13 & $\mathrm{E}$ \\
\hline & Outlook & & Outlook \\
\hline-0.2 & Positive & -0.2 & Positive \\
\hline $\mathbf{0}$ & Neutral & $\mathbf{0}$ & Neutral \\
\hline 0.2 & Negative & 0.2 & Negative \\
\hline
\end{tabular}


Appendix A2: The evolution of the risk-return Best Practice Frontier (BPF) through year

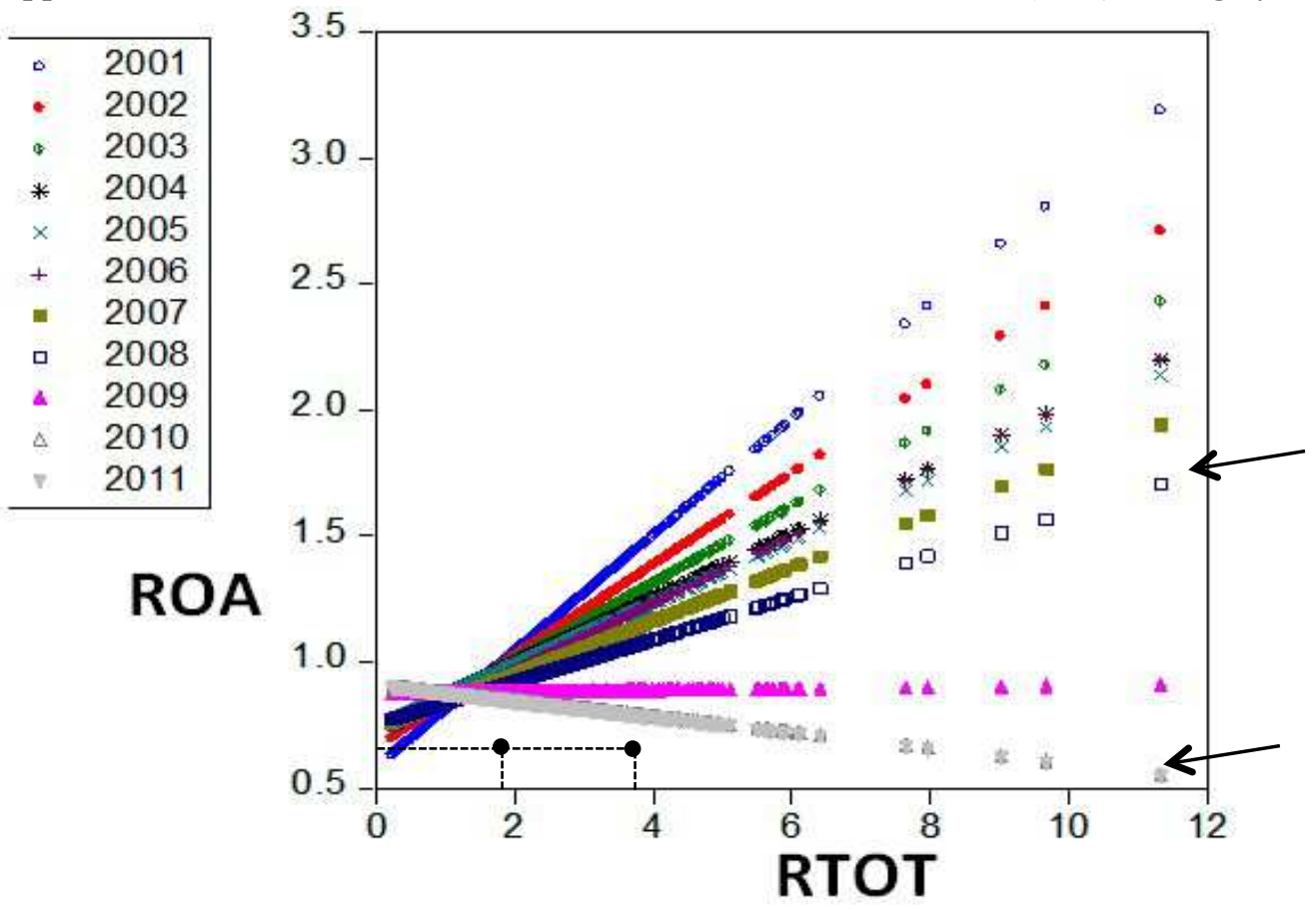

Figure 1: The Best-Practice risk-return frontier

Appendix A3: Bond spread equation (whole sample period, 1,545 issues by 47 banks, OLS estimator) Model : SPREAD $=\alpha+\beta S C O R E_{i(j), t(j)}+\gamma Y_{i(j), t(j)}+\theta X_{j}+\tau Z_{t(j)}+\varepsilon_{j}$

\begin{tabular}{|c|c|c|c|c|c|c|c|}
\hline \multicolumn{8}{|c|}{ (2001-2011, OLS estimator) } \\
\hline Variables $\quad$ Risk: & \multicolumn{3}{|c|}{ RATINGBOND } & $\begin{array}{l}\text { RATING } \\
\text { TRAD }\end{array}$ & $\begin{array}{l}\text { RATING } \\
\text { SOLID }\end{array}$ & RTOT & $\begin{array}{l}\text { Without } \\
\text { RISK }\end{array}$ \\
\hline SCORE & $\begin{array}{c}-288.12 * * * \\
(0.00)\end{array}$ & $\begin{array}{c}-202.64 * * * \\
(0.00)\end{array}$ & $\begin{array}{c}-127.25 * * * \\
(0.00)\end{array}$ & $\begin{array}{c}-178.51 * * * \\
(0.00)\end{array}$ & $\begin{array}{c}-145.90^{* * * *} \\
(0.00)\end{array}$ & $\begin{array}{c}-109.71 \text { ** } \\
(0.02)\end{array}$ & $\begin{array}{c}-150.75^{* * * *} \\
(0.00)\end{array}$ \\
\hline RISK & $\begin{array}{l}-7.32 \\
(0.13)\end{array}$ & $\begin{array}{l}-3.18 \\
(0.54)\end{array}$ & $\begin{array}{c}9.10^{* *} \\
(0.03)\end{array}$ & $\begin{array}{l}-5.19 \\
(0.20)\end{array}$ & $\begin{array}{c}1.37 \\
(0.53)\end{array}$ & $\begin{array}{c}5.46 \\
(0.26)\end{array}$ & - \\
\hline LIQDEP & $\begin{array}{c}-71.59 * * * \\
(0.00)\end{array}$ & $\begin{array}{c}-74.27 * * * \\
(0.00)\end{array}$ & $\begin{array}{c}-13.57 \\
(0.50)\end{array}$ & $\begin{array}{c}-10.93 \\
(0.60)\end{array}$ & $\begin{array}{c}-15.91 \\
(0.44)\end{array}$ & $\begin{array}{c}-11.69 \\
(0.57)\end{array}$ & $\begin{array}{c}-12.42 \\
(0.54)\end{array}$ \\
\hline LEV & $\begin{array}{c}1.40 * * * \\
(0.00)\end{array}$ & $\begin{array}{c}1.48 * * * \\
(0.00)\end{array}$ & $\begin{array}{c}1.36 * * * \\
(0.00)\end{array}$ & $\begin{array}{c}1.31 * * * \\
(0.00)\end{array}$ & $\begin{array}{c}1.28 * * * \\
(0.00)\end{array}$ & $\begin{array}{c}1.15 * * * \\
(0.01)\end{array}$ & $\begin{array}{c}1.26^{* * * *} \\
(0.00)\end{array}$ \\
\hline TAMAX & $\begin{array}{c}-53.54 * * \\
(0.03)\end{array}$ & $\begin{array}{c}-45.43^{*} \\
(0.06)\end{array}$ & $\begin{array}{c}-48.73 * * \\
(0.02)\end{array}$ & $\begin{array}{l}-74.33^{* * * *} \\
\quad(0.00)\end{array}$ & $\begin{array}{l}-55.74 * * * \\
(0.01)\end{array}$ & $\begin{array}{l}-63.94 * * * \\
(0.00)\end{array}$ & $\begin{array}{l}-61.68 * * * \\
(0.00)\end{array}$ \\
\hline MATURITY & $\begin{array}{l}2.04 * \\
(0.10)\end{array}$ & $\begin{array}{l}2.00 * \\
(0.10)\end{array}$ & $\begin{array}{c}2.85 * * \\
(0.03)\end{array}$ & $\begin{array}{c}3.07 * * \\
(0.02)\end{array}$ & $\begin{array}{c}3.17 * * \\
(0.01)\end{array}$ & $\begin{array}{c}3.54 * * * \\
(0.00)\end{array}$ & $\begin{array}{c}3.40^{* * * *} \\
(0.00)\end{array}$ \\
\hline AMOUNT & $\begin{array}{l}-10.59 * * * \\
(0.00)\end{array}$ & $\begin{array}{c}-10.42 * * * \\
(0.00)\end{array}$ & $\begin{array}{l}2.08 \\
(0.25)\end{array}$ & $\begin{array}{l}1.27 \\
(0.48)\end{array}$ & $\begin{array}{l}1.07 \\
(0.55)\end{array}$ & $\begin{array}{l}1.55 \\
(0.39)\end{array}$ & $\begin{array}{l}1.52 \\
(0.40)\end{array}$ \\
\hline SPLIT & $\begin{array}{c}12.27 * * \\
(0.03)\end{array}$ & $\begin{array}{l}9.25 \\
(0.12)\end{array}$ & $\begin{array}{c}5.54 \\
(0.26)\end{array}$ & $\begin{array}{l}8.05^{*} \\
(0.09)\end{array}$ & $\begin{array}{l}8.26^{*} \\
(0.10)\end{array}$ & $\begin{array}{l}8.69^{*} \\
(0.07)\end{array}$ & $\begin{array}{l}8.13^{*} \\
(0.08)\end{array}$ \\
\hline CYCLE & $\begin{array}{c}10.60 * * * \\
(0.00)\end{array}$ & $\begin{array}{c}8.42 * * * \\
(0.00)\end{array}$ & $\begin{array}{c}4.99 * * * \\
(0.00)\end{array}$ & $\begin{array}{c}6.22 * * * \\
(0.00)\end{array}$ & $\begin{array}{c}5.39 * * * \\
(0.00)\end{array}$ & $\begin{array}{c}5.28 * * * \\
(0.00)\end{array}$ & $\begin{array}{c}5.52 * * * \\
(0.00)\end{array}$ \\
\hline DUMCRISIS & - & $\begin{array}{c}34.66^{* * *} \\
(0.01)\end{array}$ & $\begin{array}{c}58.84 * * * \\
(0.00)\end{array}$ & $\begin{array}{c}44.78 * * * \\
(0.00)\end{array}$ & $\begin{array}{c}47.42 * * * \\
(0.00)\end{array}$ & $\begin{array}{c}45.59 * * * \\
(0.00)\end{array}$ & $\begin{array}{c}48.78 * * * \\
(0.00)\end{array}$ \\
\hline $\begin{array}{l}\text { DUMCOUNTRY } \\
\text { DUMCURRENCY }\end{array}$ & $\begin{array}{l}\text { NO } \\
\text { NO }\end{array}$ & $\begin{array}{l}\text { NO } \\
\text { NO }\end{array}$ & $\begin{array}{l}\text { YES } \\
\text { YES }\end{array}$ & $\begin{array}{l}\text { YES } \\
\text { YES }\end{array}$ & $\begin{array}{l}\text { YES } \\
\text { YES }\end{array}$ & $\begin{array}{l}\text { YES } \\
\text { YES }\end{array}$ & $\begin{array}{l}\text { YES } \\
\text { YES }\end{array}$ \\
\hline $\begin{array}{l}\text { Obs. } \\
\mathbf{R}^{2}\end{array}$ & $\begin{array}{l}857 \\
0.18\end{array}$ & $\begin{array}{l}857 \\
0.19\end{array}$ & $\begin{array}{l}857 \\
0.56\end{array}$ & $\begin{array}{l}8.48 \\
0.56\end{array}$ & $\begin{array}{l}852 \\
0.56\end{array}$ & $\begin{array}{l}857 \\
0.55\end{array}$ & $\begin{array}{l}857 \\
0.55\end{array}$ \\
\hline
\end{tabular}

P-values are shown in parentheses. $* * *, * * *$ indicate significance at the $1 \%, 5 \%, 10 \%$ levels respectively. SPREAD is the difference in basis point between the bond yield at issuance and the yield of a same currency. SCORE is computed with ROA as a measure of bank profitability and RTOT, bank portfolio total risk as a measure of bank risk RATINGBOND is the average of available bond ratings for each bond at each date. RATINGTRAD is the average of the issuer traditional ratings from Moody's and Fitch. RATINGSOLID is the average of bank individual/financial ratings. LIQDEP is the ratio of liquid assets to customer deposits and short term funding. LEV is the total liabilities to total equity ratio. TAMAX is the issuing bank's total assets to the total assets of the largest bank in the sample in the year of the issuance date. MATURITY is the number of years until the bond redemption. AMOUNT is the natural logarithm of amount of issue in euros. SPLIT is the disagreement between Moody's and Fitch bonds ratings. CYCLE is extract from the GDP with a HP filter. DUMCRISIS is a dummy equals to 1 when the bond is issued during the financial crisis; 0 otherwise. 
Appendix A4: Bond spread equation (distress and sound economic periods, GMM estimator) Model : SPREAD $=\alpha+\beta S C O R E_{i(j), t(j)}+\gamma Y_{i(j), t(j)}+\theta X_{j}+\tau Z_{t(j)}+\varepsilon_{j}$

\begin{tabular}{|c|c|c|c|c|c|c|}
\hline Variables $\quad$ Risk: & \multicolumn{2}{|c|}{ RATINGBOND } & RATING TRAD & RATING SOLID & RTOT & Without RISK \\
\hline SCORE & $\begin{array}{c}-211.89 * * * \\
(0.00)\end{array}$ & $\begin{array}{c}-140.65 * * * \\
(0.00)\end{array}$ & $\begin{array}{c}-175.42 * * * \\
(0.00)\end{array}$ & $\begin{array}{c}-152.56^{* * * *} \\
(0.00)\end{array}$ & $\begin{array}{c}-110.36^{*} \\
(0.06)\end{array}$ & $\begin{array}{c}-162.37 * * * \\
(0.00)\end{array}$ \\
\hline RISK & $\begin{array}{c}5.21 \\
(0.40)\end{array}$ & $\begin{array}{l}11.04^{*} \\
(0.10)\end{array}$ & $\begin{array}{l}-0.95 \\
(0.85)\end{array}$ & $\begin{array}{l}5.85 \\
(0.12)\end{array}$ & $\begin{array}{c}11.83^{*} \\
(0.10)\end{array}$ & - \\
\hline LIQDEP & $\begin{array}{c}6.79 \\
(0.86)\end{array}$ & $\begin{array}{l}29.93 \\
(0.42)\end{array}$ & $\begin{array}{l}27.93 \\
(0.45)\end{array}$ & $\begin{array}{c}9.24 \\
(0.80)\end{array}$ & $\begin{array}{l}21.44 \\
(0.56)\end{array}$ & $\begin{array}{l}11.71 \\
(0.74)\end{array}$ \\
\hline LEV & $\begin{array}{l}2.20 * * * \\
(0.00)\end{array}$ & $\begin{array}{c}4.00 * * * \\
(0.00)\end{array}$ & $\begin{array}{c}3.49 * * * \\
(0.00)\end{array}$ & $\begin{array}{l}3.42 * * * \\
(0.00)\end{array}$ & $\begin{array}{c}2.70 * * * \\
(0.00)\end{array}$ & $\begin{array}{l}3.16 * * * \\
(0.00)\end{array}$ \\
\hline TAMAX & $\begin{array}{l}-71.35^{* *} \\
(0.05)\end{array}$ & $\begin{array}{c}-105.34 * * * \\
(0.00)\end{array}$ & $\begin{array}{c}-122.75 * * * \\
(0.00)\end{array}$ & $\begin{array}{l}-87.59 * * \\
(0.02)\end{array}$ & $\begin{array}{c}-109.91 * * * \\
(0.00)\end{array}$ & $\begin{array}{c}-97.23 * * * \\
(0.00)\end{array}$ \\
\hline MATURITY & $\begin{array}{c}1.43 \\
(0.34)\end{array}$ & $\begin{array}{l}2.64 * \\
(0.08)\end{array}$ & $\begin{array}{c}3.55^{* *} \\
(0.02)\end{array}$ & $\begin{array}{c}3.31 * * \\
(0.02)\end{array}$ & $\begin{array}{l}3.71 * * \\
(0.02)\end{array}$ & $\begin{array}{c}2.81 * * \\
(0.04)\end{array}$ \\
\hline AMOUNT & $\begin{array}{l}-3.20 \\
(0.27)\end{array}$ & $\begin{array}{l}5.19 * \\
(0.09)\end{array}$ & $\begin{array}{l}3.28 \\
(0.29)\end{array}$ & $\begin{array}{c}2.71 \\
(0.38)\end{array}$ & $\begin{array}{c}2.29 \\
(0.46)\end{array}$ & $\begin{array}{c}3.49 \\
(0.25)\end{array}$ \\
\hline SPLIT & $\begin{array}{l}4.26 \\
(0.57)\end{array}$ & $\begin{array}{c}3.29 \\
(0.70)\end{array}$ & $\begin{array}{c}6.44 \\
(0.38)\end{array}$ & $\begin{array}{c}6.41 \\
(0.39)\end{array}$ & $\begin{array}{c}9.40 \\
(0.21)\end{array}$ & $\begin{array}{c}8.56 \\
(0.24)\end{array}$ \\
\hline CYCLE & $\begin{array}{c}7.41 * * * \\
(0.00)\end{array}$ & $\begin{array}{c}4.86 * * * \\
(0.00)\end{array}$ & $\begin{array}{c}5.74 * * * \\
(0.00)\end{array}$ & $\begin{array}{c}5.29 * * * \\
(0.00)\end{array}$ & $\begin{array}{c}5.80 * * * \\
(0.00)\end{array}$ & $\begin{array}{c}5.51 * * * \\
(0.00)\end{array}$ \\
\hline DUMCOUNTRY & NO & YES & YES & YES & YES & YES \\
\hline DUMCURRENCY & $\mathrm{NO}$ & YES & YES & YES & YES & YES \\
\hline Obs. & 445 & 445 & 440 & 440 & 440 & 440 \\
\hline $\mathbf{R}^{2}$ & 0.13 & 0.33 & 0.34 & 0.34 & 0.34 & 0.34 \\
\hline
\end{tabular}

\begin{tabular}{|c|c|c|c|c|c|c|}
\hline \multicolumn{7}{|c|}{ (Sound economic period, GMM estimator) } \\
\hline Variables & \multicolumn{2}{|c|}{ RATINGBOND } & RATING TRAD & RATING SOLID & RTOT & Without RISK \\
\hline$\overline{\text { SCORE }}$ & $\begin{array}{c}1470.47 * * * \\
(0.00)\end{array}$ & $\begin{array}{c}558.19 * * \\
(0.02)\end{array}$ & $\begin{array}{l}420.20 \\
(0.12)\end{array}$ & $\begin{array}{c}458.43^{*} \\
(0.08)\end{array}$ & $\begin{array}{c}541.46 \\
(0.17)\end{array}$ & $\begin{array}{c}491.12 * * \\
(0.04)\end{array}$ \\
\hline RISK & $\begin{array}{l}-11.83 \\
(0.14)\end{array}$ & $\begin{array}{l}3.67 \\
(0.31)\end{array}$ & $\begin{array}{l}-5.59 \\
(0.35)\end{array}$ & $\begin{array}{l}-0.86 \\
(0.74)\end{array}$ & $\begin{array}{l}4.29 \\
(0.83)\end{array}$ & - \\
\hline LIQDEP & $\begin{array}{c}-60.99 * \\
(0.09)\end{array}$ & $\begin{array}{c}-43.74 * * \\
(0.03)\end{array}$ & $\begin{array}{c}-44.54 * * \\
(0.03)\end{array}$ & $\begin{array}{c}-41.07 * * \\
(0.04)\end{array}$ & $\begin{array}{c}-44.56^{*} \\
(0.07)\end{array}$ & $\begin{array}{c}-41.56^{* *} \\
(0.04)\end{array}$ \\
\hline LEV & $\begin{array}{l}1.82 * \\
(0.07)\end{array}$ & $\begin{array}{c}0.57 \\
(0.34)\end{array}$ & $\begin{array}{c}0.89 \\
(0.17)\end{array}$ & $\begin{array}{c}1.03 \\
(0.36)\end{array}$ & $\begin{array}{c}0.61 \\
(0.41)\end{array}$ & $\begin{array}{c}0.73 \\
(0.27)\end{array}$ \\
\hline TAMAX & $\begin{array}{l}-42.81 \\
(0.22)\end{array}$ & $\begin{array}{c}0.08 \\
(0.99)\end{array}$ & $\begin{array}{c}-15.38 \\
(0.47)\end{array}$ & $\begin{array}{c}-13.20 \\
(0.60)\end{array}$ & $\begin{array}{l}-5.34 \\
(0.80)\end{array}$ & $\begin{array}{l}-7.68 \\
(0.69)\end{array}$ \\
\hline MATURITY & $\begin{array}{c}2.42 \\
(0.32)\end{array}$ & $\begin{array}{c}0.28 \\
(0.89)\end{array}$ & $\begin{array}{c}0.16 \\
(0.94)\end{array}$ & $\begin{array}{c}0.24 \\
(0.91)\end{array}$ & $\begin{array}{c}0.44 \\
(0.84)\end{array}$ & $\begin{array}{c}0.39 \\
(0.85)\end{array}$ \\
\hline AMOUNT & $\begin{array}{c}-18.50 * * * \\
(0.00)\end{array}$ & $\begin{array}{l}-1.25 \\
(0.56)\end{array}$ & $\begin{array}{l}-1.52 \\
(0.48)\end{array}$ & $\begin{array}{l}-1.32 \\
(0.54)\end{array}$ & $\begin{array}{l}-1.29 \\
(0.54)\end{array}$ & $\begin{array}{l}-1.37 \\
(0.52)\end{array}$ \\
\hline SPLIT & $\begin{array}{c}1.03 \\
(0.92)\end{array}$ & $\begin{array}{c}2.90 \\
(0.64)\end{array}$ & $\begin{array}{c}3.44 \\
(0.59)\end{array}$ & $\begin{array}{l}2.63 \\
(0.70)\end{array}$ & $\begin{array}{c}3.85 \\
(0.53)\end{array}$ & $\begin{array}{l}3.76 \\
(0.53)\end{array}$ \\
\hline CYCLE & $\begin{array}{c}8.91 * * * \\
(0.00)\end{array}$ & $\begin{array}{l}3.94 * \\
(0.06)\end{array}$ & $\begin{array}{l}3.43 \\
(0.11)\end{array}$ & $\begin{array}{l}3.59 * \\
(0.10)\end{array}$ & $\begin{array}{l}3.56^{*} \\
(0.10)\end{array}$ & $\begin{array}{l}3.58 * \\
(0.09)\end{array}$ \\
\hline DUMCOUNTRY & NO & YES & YES & YES & YES & YES \\
\hline DUMCURRENCY & $\mathrm{NO}$ & YES & YES & YES & YES & YES \\
\hline $\begin{array}{l}\text { Obs. } \\
\mathbf{R}^{2}\end{array}$ & $\begin{array}{l}412 \\
0.25\end{array}$ & $\begin{array}{l}412 \\
0.78\end{array}$ & $\begin{array}{l}408 \\
0.78\end{array}$ & $\begin{array}{l}412 \\
0.78\end{array}$ & $\begin{array}{l}412 \\
0.78\end{array}$ & $\begin{array}{l}412 \\
0.78\end{array}$ \\
\hline
\end{tabular}

P-values are shown in parentheses. $* * *, * * *$ indicate significance at the $1 \%, 5 \%, 10 \%$ levels respectively. SPREAD is the difference in basis point between the bond yield at issuance and the yield of a same currency. SCORE is computed with ROA as a measure of bank profitability and RTOT, bank portfolio total risk as a measure of bank risk RATINGBOND is the average of available bond ratings for each bond at each date. RATINGTRAD is the average of the issuer traditional ratings from Moody's and Fitch. RATINGSOLID is the average of bank individual/financial ratings. LIQDEP is the ratio of liquid assets to customer deposits and short term funding. LEV is the total liabilities to total equity ratio. TAMAX is the issuing bank's total assets to the total assets of the largest bank in the sample in the year of the issuance date. MATURITY is the number of years until the bond redemption. AMOUNT is the natural logarithm of amount of issue in euros. SPLIT is the disagreement between Moody's and Fitch bonds ratings. CYCLE is extract from the GDP with a HP filter. 